\title{
Administrative Reform in Istanbul
}

\section{F. J. C. Amos}

During the past decade Turkey has featured in the international news primarily because of its political situation and its fluctuating economic position. Although less newsworthy, important changes in the internal and local administration of the country have also been under consideration. As a preliminary step towards these reforms a number of studies were carried out within the metropolitan region of Istanbul where rapid changes and growth have probably placed a greater strain upon the administrative system than anywhere else in Turkey.

To appreciate fully the nature of the problems now being encountered, some understanding of the historical origins of the existing administrative system is necessary, for the difficulties flow not only from the inappropriateness of the current system but also from some of the cultural traditions which lay behind it.

Until 1923 Turkey was governed by the Ottoman administration, a system which was highly centralised, autocratic and more concerned with law and order than with social welfare. It was also heavily dependent upon expatriate civil servants. As a result, when Ataturk commenced his reforms he was faced with introducing a system of local administration which could be set up quickly and operated by new Turkish public servants who may not have had substantial administrative experience. To overcome these difficulties new laws were enacted which precisely defined the functions, structure and form of local authority budgets and subjected them all to strict central control.

The precise prescription of local authority activity may have served a useful purpose in setting up the system, but in the long term it has generated an administrative tradition in which staff are more concerned about conformity with regulations than with the utility of their operations. In the rural areas and smaller settlements where change is slow the inflexibility and insensitivity of the system has had limited effect, but in Istanbul where change has been both rapid and substantial, the local administration is no longer able to cope effectively with the task of urban management.

\section{Metropolitan administration}

One of the obstacles to effective urban government is the extension of the built-up area well beyond the administrative limits of Istanbul which comprise nearly four million people. This growth has embraced a number of other municipalities along the coast of the Sea of Marmora and both sides of the Bosphorus, and there is considerable uncertainty about the administrators' jurisdiction in certain areas.

This uncertainty flows in the first instance from the shortage of reliable, up-to-date maps, but more seriously from the law relating to the establishment of municipalities. Under the present system areas outside municipal boundaries are administered by the provincial authority, but an existing municipality may incorporate within its area any built-up area which comes into being on its periphery. Furthermore, any community which has a population in excess of 2,000 may declare itself a municipality and avail itself of certain tax advantages which it would not enjoy as part of the provincial administration. As a consequence, there has been an era of administrative 'tag' in which the growing provincial communities have either been taken into existing municipalities or have established their own municipal status. However, more recently the larger authorities have found that boundary extensions have brought with them disproportionate burdens and the tax advantages gained from municipal status have proved to be somewhat ephemeral. This has meant that more recent growth has remained in the provincial area, and since this growth is not mapped and boundaries are not clearly defined there is considerable administrative uncertainty.

In order to contain some of these administrative problems and to meet the needs of a rapidly growing conurbation an attempt has been made with the assistance of the World Bank to prepare a Master Plan for the metropolitan area. The Master Plan office has been in existence for more than ten years and the Plan is not likely to be completed for some years. To some extent this situation is attributable to the shortage of cartographic and statistical data but more particularly to the administrative and political tensions affecting the project. The current national administration has carried forward the centralist 
and authoritarian practices of the Ottoman regime and has therefore sought to exercise general control over the Plan, whilst individual state departments have also retained their right to make unilateral decisions about development within the Plan area. At the same time the municipalities in the area have opposed direction from the central government with varying degrees of success depending on whether or not they are of the same political persuasion as the national government.

In such frustrating conditions the staff, which has limited experience, have tended to seek shelter from administrative and political storms by restricting their activities to those specifically prescribed by statute and ordinance. Under such conditions the possibility of producing a useful plan is very limited. However, recently the local authorities in the area have formed themselves into the Union of Marmora, and since they are of the same political persuasion as the national government they are looking for ways in which a more constructive and collaborative atmosphere can be created for the Master Plan project. Once this is achieved it is likely that the benefits of preparing the Master Plan could sustain the operation, since this is a prior condition for further World Bank assistance for sewerage and water supply programmes.

\section{Managing the physical environment}

The growth of Istanbul has not been solely due to direct migration from rural to urban areas. Growth has been accelerated and given a special character because many rural Turks enter Europe on work contracts and then return to settle in Istanbul and to bring their families to join them from the rural areas. This has meant that most households have some capital and European attitudes (brought home by the 'guest worker') and strong rural traditions (in the 'guest worker's' family). The outcome has been a massive demand for accommodation both in the existing built-up area and on the periphery. Land and property prices have escalated and there is intensive pressure for development and redevelopment.

In the absence of adequate maps or reliable records of land ownership the opportunities for planning and controlling development are limited. However, the Municipality of Istanbul does have a building control system which embodies some rudimentary planning operations and there is a special section which lays out and issues titles to land in new squatter areas. This operation has been relatively successtul but is seriously handicapped by the fact that it can only move in to do its work after squatting has begun.

Clearly, both at metropolitan and city levels effective planning is seriously hampered by the inadequate supply of cartographic and statistical information, and investigations are in hand with a view to making existing material more readily available and to supplementing it by further work.

But given an improved political and administrative environment for planning and given an improved data base two other factors must be taken into account. First the building permit system needs to be changed. Although this system was introduced to regulate development, its control function is now perfunctory and it is largely regarded as a source of revenue through the charges made for permits. The second and more fundamental factor relates to the public attitudes and the nature of the planning process. Istanbul has always been a great trading centre and it is inevitable in a period of accommodation scarcity that land and property should be seen as marketable commodities without much regard for environmental factors, except in so far as they conspicuously affect value. In these circumstances planning can only be effective if it is used as a tool to steer development and influence market forces. It could be that from this type of approach a planning system could be evolved which would be more positive and creative than that currently in operation in the United Kingdom.

\section{Financial management}

The Municipality has at the present time little opportunity for sound financial management since it is in a state of perpetual uncertainty about its income. This is because approximately half of its revenue is derived from certain proportions of national taxes allocated to the Municipality. The actual sums payable are only computed when the accounts for the tax year are closed and therefore the Municipality only knows what is due from the central government some months after the end of the year in which it has incurred expenditure. Furthermore, about 15 per cent of the national tax contribution is derived from customs income which may fluctuate violently with swings in international trading conditions. In other cases the national government has neglected to pay over the allocated proportion of tax. As a result, the Municipality has to raise 
loans with the State Bank to meet its commitments, and every few years these loans are paid off by the national government.

The situation is rendered even more difficult by the fact that the form of budget accounting is precisely prescribed by statute and does not provide a balance sheet or similar statement. The Municipality has therefore been advised that in addition to the statutory documents it should prepare for its own purposes a budget (based on an assumed income) and a set of accounts which will allow it to exercise proper internal control over its financial transactions.

\section{Decision processes}

The Municipality is governed by a council which is deliberative but vested with certain ratifying powers, and a Mayor who, with a group of Assistant Mayors, exercises executive authority over nearly 60 departments and agencies.

Control is achieved by placing groups of these departments under each of the Assistant Mayors, and all formal communication between departments must pass through the appropriate Assistant Mayor. Also, because of its size, the city has been divided into ten sub-districts, each of which operates as an autonomous unit answerable only to the Mayor.

Thus communication and control is highly centralised, and since many authorisations for small matters require more than 20 signatures the system is also highly congested and cumbersome.

A succession of Mayors have found the system unsatisfactory and have made attempts to improve it. Most notable amongst these has been the introduction of a new class of public officer to bring into the service younger graduates who would have a more progressive approach than the established public servants in statutory posts. Whilst this introduced new blood, it has also introduced new problems because the new staff are paid higher salaries and this is resented by the old staff. The latter have therefore become obstructive, since their signature is statutorily required on many documents.

More recently, with the support of OECD the Institute of Local Government Studies has been advising the Mayor how administrative improvements could be made. The main recommendation has been that the Municipality needs some clear guidelines to give direction to the multitude of decisions which have to be made in day-to-day operations. For this purpose it has been proposed that the Assistant Mayors delegate to the heads of departments responsibility for routine management and thereby give themselves more time to work with the Mayor in formulating and implementing overall policy.

The purpose of the proposals is not to create a highly complex corporate management structure but to create the opportunity for the chief executive officers to form some general views about what should be happening in and to the Municipality and how it may be achieved. Given this and the basic organisation and tools for financial and environmental management it will be for them to develop their own system.

\section{Conclusion}

There are some serious problems arising from the Turkish Government's wish to see how the administrative reform works out in Istanbul before applying it more generally.

The first is that with such a highly centralised administration many of the problems of the Municipality flow from the attitudes and the practices of central government departments which are not committed to reform, and are disinclined to make exceptions of Istanbul or anywhere else.

Secondly, there is an implicit danger that if some measures are thought to be desirable they may be universalised and applied in inappropriate circumstances.

Thirdly, if statutory procedures must be sustained during the period of experiment, this may create intolerable work burdens on some staff.

Fourthly, traditional systems have shaped the attitudes of staff and it may be more important to change attitudes than practices. But it is more difficult to effect such changes, and especially so when this is attempted as part of an experiment which by definition may be transitory.

However, where external constraints to change are substantial it may be that the best way to achieve reform is to create constructively critical attitudes in people who can pick away at the obstacles to change. 